\title{
Special Needs to Prescribe Exercise Intensity for Scientific Studies
}

\author{
Peter Hofmann ${ }^{1,2,3}$ and Gerhard Tschakert ${ }^{1}$ \\ ${ }^{1}$ Human Performance Research, Karl-Franzens-University, Max-Mell-Allee 11, 8010 Graz, Austria \\ ${ }^{2}$ Medical University Graz, Max-Mell-Allee 11, 8010 Graz, Austria \\ ${ }^{3}$ Institute of Sports Science, Karl-Franzens-University Graz, Mozartgasse 14/1, 8010 Graz, Austria \\ Correspondence should be addressed to Peter Hofmann, peter.hofmann@uni-graz.at \\ Received 12 October 2010; Accepted 9 November 2010 \\ Academic Editor: Demosthenes Panagiotakos
}

Copyright ( 2011 P. Hofmann and G. Tschakert. This is an open access article distributed under the Creative Commons Attribution License, which permits unrestricted use, distribution, and reproduction in any medium, provided the original work is properly cited.

\begin{abstract}
There is clear evidence regarding the health benefits of physical activity. These benefits follow a dose-response relationship with a particular respect to exercise intensity. Guidelines for exercise testing and prescription have been established to provide optimal standards for exercise training. A wide range of intensities is used to prescribe exercise, but this approach is limited. Usually percentages of maximal oxygen uptake $\left(\mathrm{VO}_{2}\right)$ or heart rate $(\mathrm{HR})$ are applied to set exercise training intensity but this approach yields substantially variable metabolic and cardiocirculatory responses. Heterogeneous acute responses and training effects are explained by the nonuniform heart rate performance curve during incremental exercise which significantly alters the calculations of $\% \mathrm{HR}_{\max }$ and $\% \mathrm{HRR}$ target $\mathrm{HR}$ data. Similar limitations hold true for using $\% \mathrm{VO}_{2 \max }$ and $\% \mathrm{VO}_{2} \mathrm{R}$. The solution of these shortcomings is to strictly apply objective submaximal markers such as thresholds or turn points and to tailor exercise training within defined regions.
\end{abstract}

\section{Introduction}

Evidence regarding the health benefits of physical activity is overwhelming and there is no doubt about the impact of exercise training on health and fitness [1-3]. Exercise training improves exercise tolerance as well as symptoms of particular diseases and increases submaximal and maximal exercise capacity [2-5]. Furthermore, exercise training improves quality of life and reduces hospitalisation, morbidity, and mortality [6-10]. There is clear evidence that exercise training therapy positively affects chronic diseases in general $[2,5]$, and therefore exercise training is usually an integral part of secondary prevention and specifically of cardiac rehabilitation [11]. However, the applied exercise prescriptions in the underlying training interventions studies vary considerably. Corra et al. [11] suggested the usually applied exercise modalities to be safe, however, the question about the most effective training mode still remains to be answered.

As presented by the American College of Sports Medicine (ACSM) the essential components of a systematic individualized exercise prescription include the appropriate mode(s), intensity, duration, frequency, and progression of exercise training at which exercise intensity is considered as the most important of the primary variables [12]. With respect to exercise intensity, we may suggest that the optimal individually tailored exercise prescription for each single subject can only be determined from an objective evaluation of the individuals' response to exercise. This implies the standard use of cardiopulmonary exercise testing for the functional evaluation of healthy subjects and patients and the determination of individual reference points for every single subject [13-16]. It seems obvious that the relative but not the absolute intensity is the major impact for an exercise-induced increase in several mRNA [17] pointing to the importance of individual reference points for exercise prescription, independent of health and fitness status.

Health and fitness benefits associated with exercise training follow a dose-response relationship where the importance of optimal individual exercise intensity has been highlighted $[5,17]$. That applies particularly to subjects with disease but also for apparently healthy subjects and athletes.

However, in the numerous studies available, various combinations of the above-mentioned components of exercise prescription were applied, and up to now there is 
TABLE 1: Overview of recommendations for physical activity and public health in healthy adults and patients.

\begin{tabular}{|c|c|c|c|}
\hline Recommendation & Intensity & Duration & Frequency \\
\hline $\begin{array}{l}\text { ACSM [18] resource } \\
\text { manual for guidelines } \\
\text { for exercise testing and } \\
\text { prescription healthy } \\
\text { individuals }\end{array}$ & $\begin{array}{l}\text { moderate intensity } \\
40 \%-59 \% \mathrm{HRR}\left(\mathrm{VO}_{2} \mathrm{R}\right) \\
\text { vigorous intensity } \geq 60 \% \\
\mathrm{HRR}\left(\mathrm{VO}_{2} \mathrm{R}\right)\end{array}$ & $\begin{array}{l}20-60 \mathrm{~min} \cdot \mathrm{day}^{-1} \\
\text { continuous or } \\
\text { intermittent in bouts of } \\
\text { at least } 10 \mathrm{~min} \\
20-60 \mathrm{~min} \cdot \mathrm{day}^{-1} \\
\text { continuous or } \\
\text { intermittent in bouts of } \\
\text { at least } 10 \mathrm{~min}\end{array}$ & $\begin{array}{l}\min . \text { of } 5 \mathrm{~d} \cdot \mathrm{wk}^{-1} \mathrm{~min} . \\
3 \mathrm{~d} \cdot \mathrm{wk}^{-1}\end{array}$ \\
\hline CAD + MI patients & $40 \%-85 \%$ HRR $\left(\mathrm{VO}_{2} \mathrm{R}\right)$ & & \\
\hline HF patients & $40 \%-70 \%$ HRR $\left(\mathrm{VO}_{2} \mathrm{R}\right)$ & & \\
\hline $\begin{array}{l}\text { ACSM [19] guidelines } \\
\text { for exercise testing and } \\
\text { prescription }\end{array}$ & $40 \%-85 \%$ HRR $\left(\mathrm{VO}_{2} \mathrm{R}\right)$ & $20-60 \mathrm{~min} \cdot \mathrm{day}^{-1}$ & $3-5 \mathrm{~d} \cdot \mathrm{wk}^{-1}$ \\
\hline $\begin{array}{l}\text { ACSM/AHA [20] } \\
\text { healthy adults 18-65 } \\
\text { years of age }\end{array}$ & $\begin{array}{l}\text { moderate intensity } \\
\text { (between } 3.0 \text { and } 6.0 \text { METs) } \\
\text { vigorous intensity (above } \\
6.0 \mathrm{METs} \text { ) }\end{array}$ & $\begin{array}{l}\text { at least } 30 \mathrm{~min} \cdot \text { day }^{-1} \\
\text { continuous or } \\
\text { intermittent in bouts of } \\
\text { at least } 10 \mathrm{~min} \text { each at } \\
\text { least } 20 \mathrm{~min} \cdot \text { day }^{-1} \\
\text { continuous activity }\end{array}$ & $\begin{array}{l}\min \text {. of } 5 \mathrm{~d} \cdot \mathrm{wk}^{-1} \mathrm{~min} \text {. of } \\
3 \mathrm{~d} \cdot \mathrm{wk}^{-1}\end{array}$ \\
\hline $\begin{array}{l}\text { ACSM/AHA [21] older } \\
\text { adults aged }>65 \text { years }\end{array}$ & $\begin{array}{l}\text { moderate intensity ( } 5-6 \text { on } \\
\text { a } 10 \text {-point scale)vigorous } \\
\text { intensity ( } 7-8 \text { on a } 10 \text {-point } \\
\text { scale) }\end{array}$ & $\begin{array}{l}\text { at least } 30 \mathrm{~min} \cdot \text { day }^{-1} \\
\text { continuous or } \\
\text { intermittent (in bouts of } \\
\text { at least } 10 \mathrm{~min} \text { each) } \\
\text { activity at least } \\
20 \mathrm{~min} \cdot \text { day }^{-1} \\
\text { continuous activity }\end{array}$ & $\begin{array}{l}\min \text {. of } 5 \mathrm{~d} \cdot \mathrm{wk}^{-1} \mathrm{~min} \text {. of } \\
3 \mathrm{~d} \cdot \mathrm{wk}^{-1}\end{array}$ \\
\hline $\begin{array}{l}\text { AHA [22] coronary } \\
\text { artery disease }\end{array}$ & $\begin{array}{l}\text { moderate intensity } \\
(40 \%-60 \% \text { of HRR }) \\
\text { vigorous intensity as } \\
\text { tolerated }(60 \%-85 \% \text { of } \\
\text { HRR })\end{array}$ & at least $30 \mathrm{~min} \cdot \mathrm{day}^{-1}$ & $\min$. of $3 \mathrm{~d} \cdot \mathrm{wk}^{-1}$ \\
\hline $\begin{array}{l}\text { ACSM [23] } \\
\text { hypertension }\end{array}$ & $\begin{array}{l}\text { moderate intensity } \\
\left(40 \%-60 \% \text { of } \mathrm{VO}_{2} \mathrm{R}\right) \\
\text { vigorous intensity } \\
\text { acceptable for selected } \\
\text { adults }\end{array}$ & $\begin{array}{l}30-60 \mathrm{~min} \cdot \mathrm{day}^{-1} \\
\text { continuous or } \\
\text { intermittent (in bouts of } \\
\text { at least } 10 \mathrm{~min} \text { each) } \\
\text { activity }\end{array}$ & $\begin{array}{l}\text { most, preferably all days } \\
\text { per week }\end{array}$ \\
\hline AHA [24] stroke & $50 \%-80 \%$ of $\mathrm{HR}_{\max }$ & $\begin{array}{l}20-60 \mathrm{~min} / \mathrm{session} \text { (or } \\
\text { multiple } 10 \mathrm{~min} \\
\text { sessions) }\end{array}$ & $3-7 \mathrm{~d} \cdot \mathrm{wk}^{-1}$ \\
\hline $\begin{array}{l}\text { American Diabetes } \\
\text { Association [21] type } 2 \\
\text { diabetes }\end{array}$ & $\begin{array}{l}\text { moderate intensity } \\
\left(50 \%-70 \% \text { of } \mathrm{HR}_{\max }\right) \\
\text { vigorous intensity }(>70 \% \\
\left.\text { of } \mathrm{HR}_{\max }\right)\end{array}$ & $\begin{array}{l}\text { at least } 150 \mathrm{~min} \cdot \mathrm{wk}^{-1} \\
\text { moderate and/or at least } \\
90 \mathrm{~min} \cdot \mathrm{wk}^{-1} \text { vigorous } \\
\text { activity }\end{array}$ & $\begin{array}{l}\min \text {. of } 3 \mathrm{~d} \cdot \mathrm{wk}^{-1} \text {, no } \\
\text { more than } 2 \text { consecutive } \\
\text { days without activity }\end{array}$ \\
\hline
\end{tabular}

HRR: heart rate reserve; $\mathrm{VO}_{2} \mathrm{R}$ : oxygen consumption reserve.

CAD: coronary artery disease; MI: myocardial infarction; HF: heart failure.

no consistent model of exercise prescription fulfilling the optimal individual needs for training studies in healthy subjects and patients.

Guidelines for exercise testing and prescription have been established to provide optimal standards for exercise training in healthy subjects as well as for cardiac rehabilitation and secondary prevention programs $[12,14-16]$. These standards give a broad spectrum of possibilities for the attending physician by defining safe and effective upper and lower limits in general terms. However, this wide range of intensities for the prescription of exercise recommended in these guidelines (Table 1) makes it rather difficult to make an appropriate choice of exercise intensity for a single individual. The application of various exercise intensities within this wide spectrum gives good reasons for differences in the training responses and the heterogeneity in outcome seen in all kinds of different exercise training intervention studies limiting the comparability of data $[25,26]$.

The questions to be answered are which optimal choice of intensity for an individual is safe (upper limit) and effective 

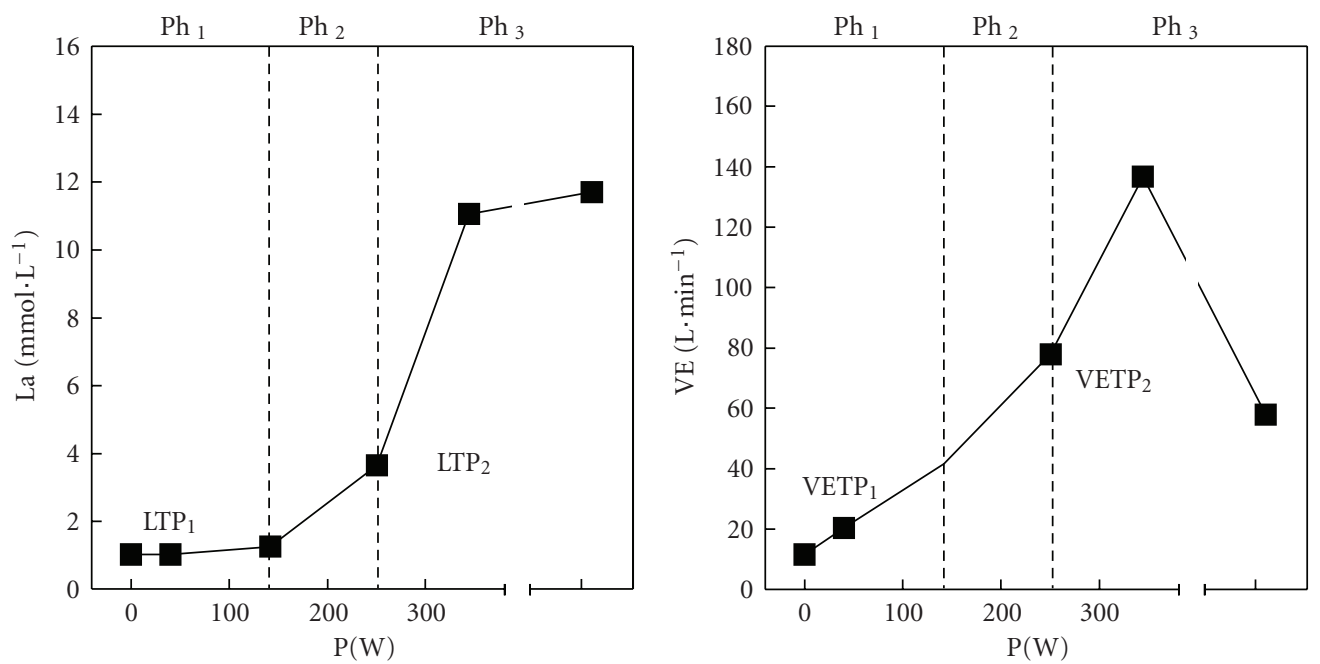

(a)
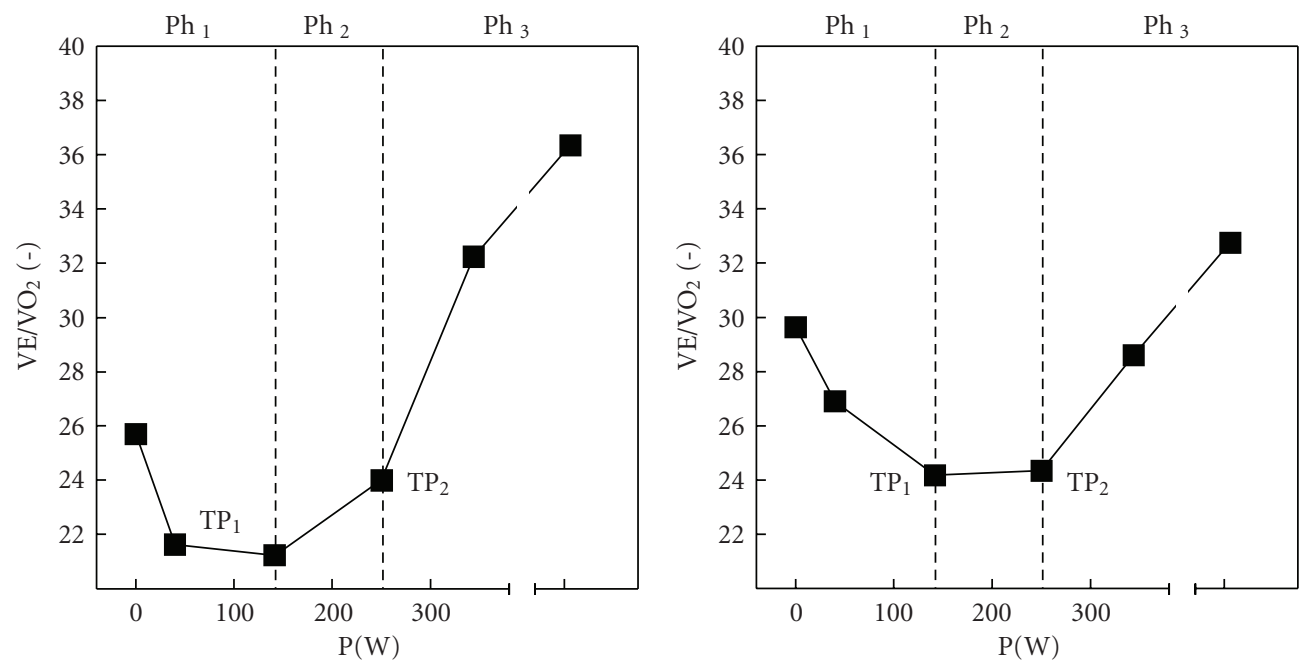

(c)

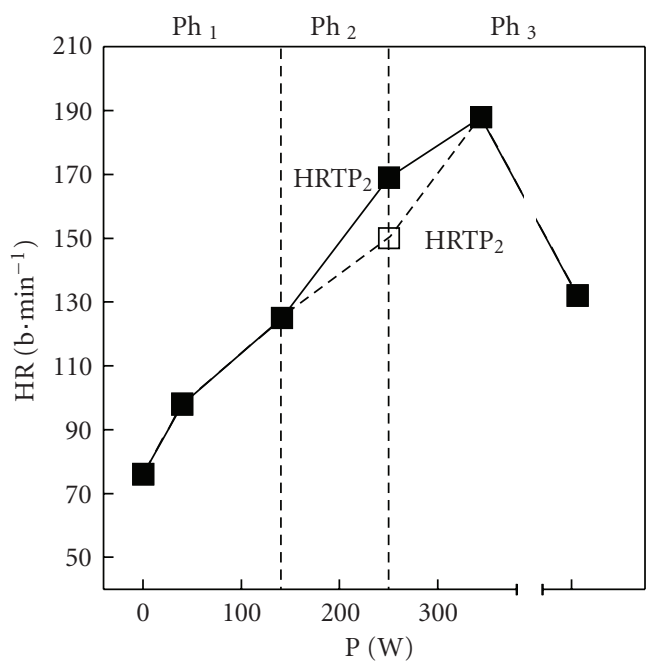

(d)

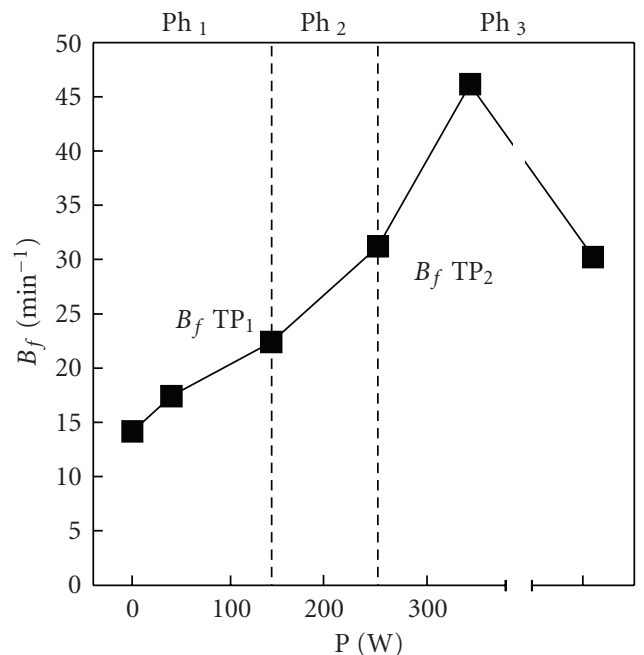

(e)

(f)

FIGURE 1: Schematic representation of first- and second- turn points of selected variables (La blood lactate concentration; VE: ventilation; $\mathrm{VE} / \mathrm{VO}_{2}$ : equivalent for oxygen uptake; $\mathrm{VE} / \mathrm{VCO}_{2}$ : equivalent for carbon dioxide output; HR: heart rate; $B_{f}$ : breathing frequency) and distinct phases (Ph 1-3) of energy supply determined from young healthy male subjects. Ph 1: no increase of blood lactate concentration above baseline during constant load exercise. Ph 2: increased but steady state blood lactate concentration during constant load exercise. Ph 3 : continuous increase of blood lactate concentration during constant load exercise leading to early termination of exercise. 
(lower limit) and, even much more important, which is the optimal definition of exercise intensity for scientific investigations to evaluate training effects in healthy subjects and patients suffering from various chronic diseases $[13,27,28]$.

As exercise intensity is suggested to be the leading component of exercise prescription we draw our attention especially to this specific component, although one should be aware of the fact that all components of exercise training and their combination are also substantial parts of the action of exercise training.

\section{Exercise Intensity}

It is suggested that physiological benefits gained from exercise training are primarily dependent on the intensity of the training stimulus [32]. The intensity should be above a minimal level required to induce a training effect which was shown to be at $40 \%-49 \%$ heart rate reserve (HRR) or $64 \%-70 \%$ maximal heart rate $\left(\mathrm{HR}_{\max }\right)$ or even lower at $30 \%$ oxygen uptake reserve $\left(\mathrm{VO}_{2} \mathrm{R}\right)$ in unfit subjects [19]. However, clearly defined standards for the lower limit of prescriptible aerobic training intensity have not been established yet, neither in healthy individuals nor in cardiac patients [27]. As it is well known in work physiology that staying below $33 \%-50 \%$ maximal oxygen uptake $\left(\mathrm{VO}_{2 \max }\right)$ is necessary to sustain eight-hour work shifts [33], we may assume this threshold to be a limit which has to be exceeded to gain training effects.

The upper limit of prescriptible aerobic training intensity is crucial for safety and control of exercise-related risks [27]. Therefore, exercise prescription should include individually prescribed upper limits for exercise intensities. Several studies showed that in general training using higher intensities gains significantly greater improvements than moderate or low intensity exercise training with the same volume of exercise [34-36] or similar energy expenditure [37]. These findings led to a revival of intense interval-type exercise training [38-42]. However, approaching the limits of tolerance requires more precise and sophisticated diagnostics and exercise intensity prescriptions particularly for patients.

\section{Exercise Intensity Prescription by Means of $\mathbf{H R}_{\max }$ and $\mathbf{H R R}$}

Standard variables used to prescribe exercise intensity are percentages of maximal heart rate $\left(\mathrm{HR}_{\max }\right)$ and maximal oxygen uptake $\left(\mathrm{VO}_{2 \max }\right)$ as well as calculated subfractions of these variables such as $\mathrm{HR}$ reserve ( $\mathrm{HRR})$ and $\mathrm{VO}_{2}$ reserve $\left(\mathrm{VO}_{2} \mathrm{R}\right)$.

Heart rate is the most common parameter to determine target exercise training intensity. The usual recommendations are in a range between $64 \%$ and $70 \%$ to $94 \%$ of $\mathrm{HR}_{\max }$ or between $40 \%$ and $50 \%$ to $85 \%$ of $\mathrm{HRR}$ (and $\mathrm{VO}_{2} \mathrm{R}$ ) [19] (Table 1). However, the HR response to incremental exercise was shown to be neither linear nor uniform $[29,30$, 43] (Figure 2). Consequently, this heterogeneous character of the heart rate performance curve (HRPC) significantly alters the calculations of $\% \mathrm{HR}_{\max }$ and $\% \mathrm{HRR}$ target training
HR as shown previously [29, 44-47]. It is demonstrated in Figure 2 that two healthy young subjects with more or less identical maximal power output $\left(P_{\max }\right)$ and submaximal power output at the first lactate turn point $\left(\mathrm{P} \mathrm{LTP}_{1}\right)$ and at the second lactate turn point $\left(\mathrm{P} \mathrm{LTP}_{2}\right)$ vary considerably in their $\mathrm{HR}$ response, more precisely in their $\% \mathrm{HR}_{\max }$ at $\mathrm{P}$ $\mathrm{LTP}_{2}$. So calculating the same target training upper limits by means of $\% \mathrm{HR}_{\max }$ or $\% \mathrm{HRR}$ gives a completely different training load with respect to the reference turn points $[13,25,29,46,47]$. More importantly most patients with cardiovascular disease present an upward deflection of the heart rate performance curve [48] stressing the importance of this problem in this kind of population (Figure 2). Using $\% \mathrm{HR}_{\max }$ methods such as the common $85 \% \mathrm{HR}_{\max }$ model will lead to an overestimation of the individual training heart rate by at least $5 \%-10 \%$ and up to $40 \%$ in single cases [44]. Figure 3 shows the error of estimate caused by different \% $\mathrm{HR}_{\max }$ at $\mathrm{P} \mathrm{LTP}_{2}$ if fixed percentages of $\mathrm{HR}_{\max }$ or $\mathrm{HRR}$ $[29,44]$ are applied. Similar results were also shown by Tabet et al. [46] and Wonisch et al. [47].

Additional concerns may be raised if true maximal HR or oxygen uptake values can be obtained in untrained subject and especially in patients $[49,50]$. Because of local leg fatigue, tests may end prematurely before cardiopulmonary endpoints have been achieved [19].

\section{Exercise Intensity Prescription by Means of $\mathrm{VO}_{2 \max }$ and $\mathrm{VO}_{2} \mathrm{R}$}

Oxygen uptake-based prescriptions are frequently used for individual training but more often for exercise training studies since $\mathrm{VO}_{2 \max }$ is accepted as the criterion measure of cardiorespiratory fitness. Several studies $[32,51]$ indicated that among healthy adults, $\% \mathrm{VO}_{2} \mathrm{R}$ is more closely related to $\% \mathrm{HRR}$ than it is to $\% \mathrm{VO}_{2 \max }$, although there is a disparity of $10 \%$ between the two first methods mentioned above. It has also been shown that the disparity increases with age [32]. These findings, in addition to the disparity between $\% \mathrm{HRR}$ and $\% \mathrm{VO}_{2 \max }$ which is greater at low intensities and among low fit individuals, provoked the ACSM to adopt the use of $\% \mathrm{VO}_{2} \mathrm{R}$ in place of $\% \mathrm{VO}_{2 \max }$ when prescribing exercise intensity among healthy adults and patients [51]. It is a common assumption that not only absolute oxygen uptake at the anaerobic threshold but also $\% \mathrm{VO}_{2 \max }$ at this threshold is higher in trained subjects [52]. Similarly as shown for HR, exercise prescription based on fixed percentages of $\mathrm{VO}_{2 \max }$ will lead to an overestimation of target training intensity in patients with limited exercise tolerance and with a first lactate turn point appearing already at a very low power output [53]. In accordance with that, Scharhag-Rosenberger et al. [26] emphasized that applying the same fixed percentage of maximal oxygen uptake yields substantially variable acute metabolic responses across subjects (Figure 4) and that different training stimuli with respect to individual submaximal reference turn points $\left(\mathrm{P} \mathrm{LTP}_{1}, \mathrm{P} \mathrm{LTP}_{2}\right)$ may be expected.

In addition, several studies have shown marked individual differences in responsiveness to exercise training 


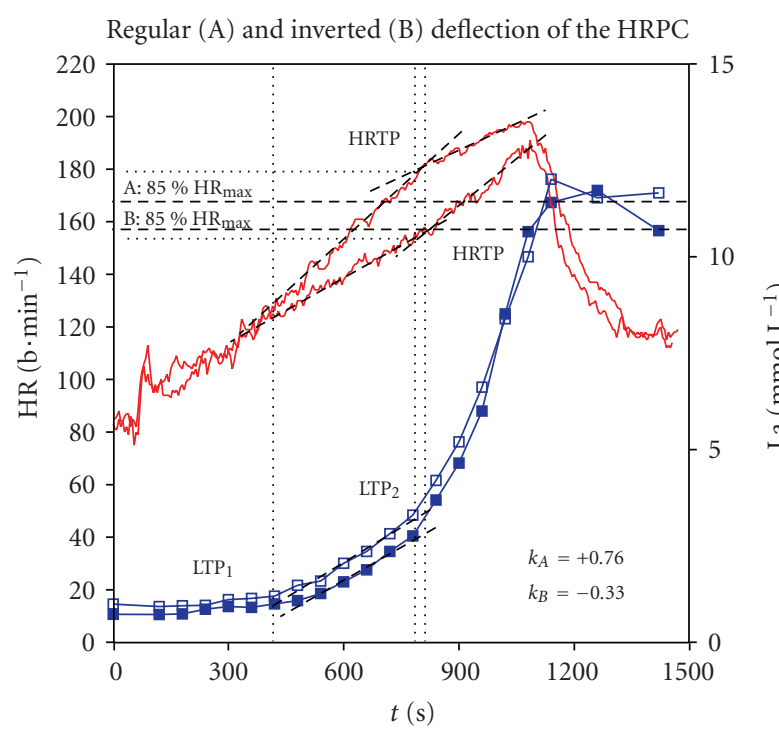

(a)

$\begin{array}{ll}\text { A } & \text { B } \\ \text { HR HRTP }=180 \mathrm{~b} \cdot \mathrm{min}^{-1} & \mathrm{HR} \mathrm{HRTP}=157 \mathrm{~b} \cdot \mathrm{min}^{-1} \\ \mathrm{HR} \mathrm{LTP}_{2}=179 \mathrm{~b} \cdot \mathrm{min}^{-1} & \mathrm{HR} \mathrm{LTP}_{2}=155 \mathrm{~b} \cdot \mathrm{min}^{-1} \\ \mathrm{HR} \mathrm{LTP}_{1}=139 \mathrm{~b} \cdot \mathrm{min}^{-1} & \mathrm{HR} \mathrm{LTP}_{1}=127 \mathrm{~b} \cdot \mathrm{min}^{-1} \\ \mathrm{HR} \mathrm{LTP}_{2}=90.4 \% \mathrm{HR}_{\max } & \mathrm{HR} \mathrm{LTP}_{2}=83.4 \% \mathrm{HR}_{\max } \\ 70 \% \mathrm{HR}_{\max }=139 \mathrm{~b} \cdot \mathrm{min}^{-1} & 70 \% \mathrm{HR}_{\max }=130 \mathrm{~b} \cdot \mathrm{min}^{-1} \\ 80 \% \mathrm{HR}_{\max }=158 \mathrm{~b} \cdot \mathrm{min}^{-1} & 80 \% \mathrm{HR}_{\max }=148 \mathrm{~b} \cdot \mathrm{min}^{-1} \\ 85 \% \mathrm{HR}_{\max }=168 \mathrm{~b} \cdot \mathrm{min}^{-1} & 85 \% \mathrm{HR}_{\max }=157 \mathrm{~b} \cdot \mathrm{min}^{-1} \\ 90 \% \mathrm{HR}_{\max }=178 \mathrm{~b} \cdot \mathrm{min}^{-1} & 90 \% \mathrm{HR}_{\max }=167 \mathrm{~b} \cdot \mathrm{min}^{-1} \\ 70 \% \mathrm{HRR}=163 \mathrm{~b} \cdot \mathrm{min}_{-1} & 70 \% \mathrm{HRR}=154 \mathrm{~b} \cdot \mathrm{min}_{-1} \\ 80 \% \mathrm{HRR}=174 \mathrm{~b} \cdot \mathrm{min}^{-1} & 80 \% \mathrm{HRR}=164 \mathrm{~b} \cdot \mathrm{min}^{-1} \\ 85 \% \mathrm{HRR}=180 \mathrm{~b} \cdot \mathrm{min}^{-1} & 85 \% \mathrm{HRR}=170 \mathrm{~b} \cdot \mathrm{min}^{-1} \\ 90 \% \mathrm{HRR}=186 \mathrm{~b} \cdot \mathrm{min}^{-1} & 90 \% \mathrm{HRR}=175 \mathrm{~b} \cdot \mathrm{min}^{-1}\end{array}$

(b)

Figure 2: Accuracy of target training heart rate dependent on the time course of the Heart Rate Performance Curve. The same relative intensity of $85 \% \mathrm{HR}_{\max }$ (usual upper limit) gives different work load related to the anaerobic threshold ( $\left.\mathrm{LTP}_{2}\right)$ [29]. Subject (A) 85\% HR $\max$

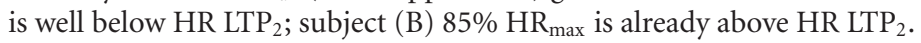

interventions. For example, impacts of standardized training programs on $\mathrm{VO}_{2 \max }$ have ranged from almost no gain up to $100 \%$ increase in large groups of sedentary individuals [5456]. Similar results have been reported by Hansen et al. [57] in cardiac patients. Data from the HERITAGE family study [56] showed that subjects who exercised at an HR associated with the same relative $\% \mathrm{VO}_{2 \max }$ intensity vary substantially in their training response, in their rate of increase in power output over a 20 -wk training program, and in their improvement of $\mathrm{VO}_{2 \max }$. However, age, sex, race, and initial fitness had little impact on these individual differences [54, 56], and a genetic component to explain these differences was suggested $[58,59]$. However, one may suggest also the mode of exercise prescription to be a possible factor of influence $[25,26,28]$. Furthermore, similar as discussed for $\mathrm{HR}_{\max }$ we may critically argue if a true $\mathrm{VO}_{2 \max }$ can be obtained in untrained obese subjects [60] and patients [61].

Most of the prescription models used for exercise training interventions refer to maximal variables measured from incremental ergometer exercise giving a wide range of intensities (Table 1); however, given the aforementioned limitations of these models, the recommendations to use turn point models are increasing $[13,26,62]$.

\section{Exercise Intensity Prescription by Means of Submaximal Markers-The Turn Point Model}

Scharhag-Rosenberger et al. [26] criticized the "traditional" concept to prescribe exercise intensity by means of maximal values, and they suggested that it might be more appropriate to consider the metabolic demand of exercise applying a threshold concept. Several authors $[25,46]$ have pointed out the shortcomings of training prescriptions without defining a threshold but applying fixed percentages of $\mathrm{HR}_{\max }$ or $\mathrm{HRR}$ leading to differing levels of metabolic stress across subjects (see Figures 2 and 3). Recently Salvadego et al. [63] suggested that exercise prescription and evaluation should be made at workloads chosen with respect to submaximal markers from incremental exercise and not as percentages of $\mathrm{VO}_{2 \max }$. Binder et al. [13] showed the advantage of applying a three phase model, using the first- and the second- turn point approach presented earlier by Davis et al. [64] and later on by our own working group $[29,30,43,65-67]$ and other authors [68]. This method, however, is surprisingly only marginally described in the current guidelines.

This concept is known as the three-phase-model presented already by Skinner and McLellan [69]. As there are numerous concepts to determine thresholds, this topic has been discussed extensively during the past decades. From all these concepts two different main approaches can be deduced:

(1) thresholds indicating the first increase in blood lactate concentration originally defined as the "anaerobic threshold" (AT) by Wasserman and Mcllroy [70] and mostly described as the "aerobic threshold" equivalent to the first-turn point for lactate ( $\mathrm{La})$, ventilation (VE), and the oxygen equivalent $\left(\mathrm{VE} / \mathrm{VO}_{2}\right)$, and breathing frequency $\left(B_{f}\right)[13,62]$,

(2) thresholds indicating the maximal lactate steady state which is significantly higher than the first-turn point and mostly described as the "anaerobic threshold" equivalent to the second-turn point for La, VE, $B_{f}$, $\mathrm{VE} / \mathrm{VO}_{2}$, and $\mathrm{VE} / \mathrm{VCO}_{2}[13,29,62,65-67,71]$ as well as to the heart rate turn point (HRTP) as earlier shown by our own working group $[29,30,65]$. 


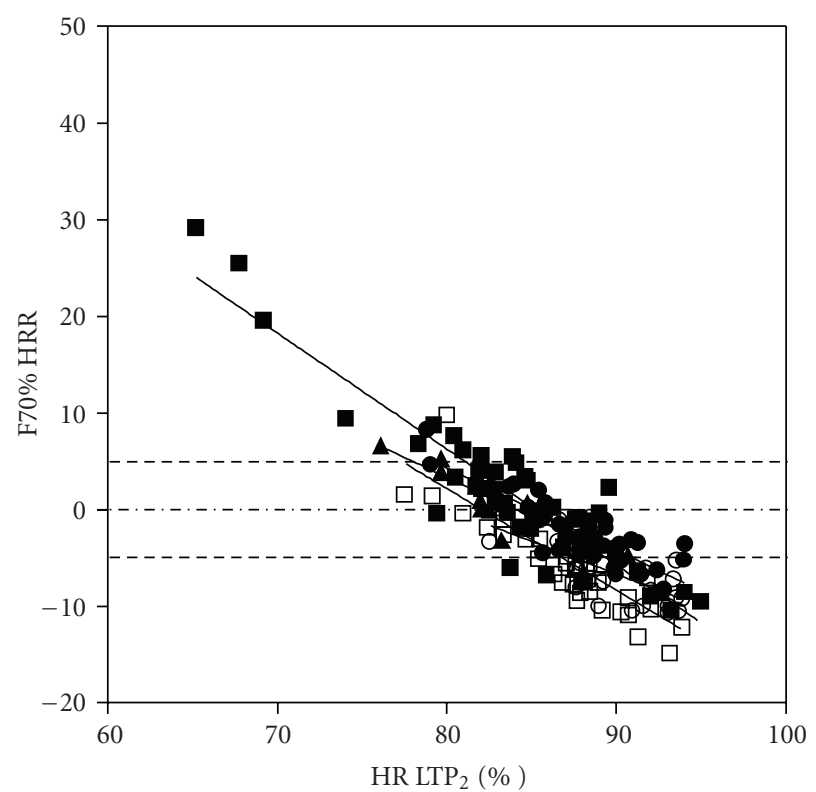

(a)

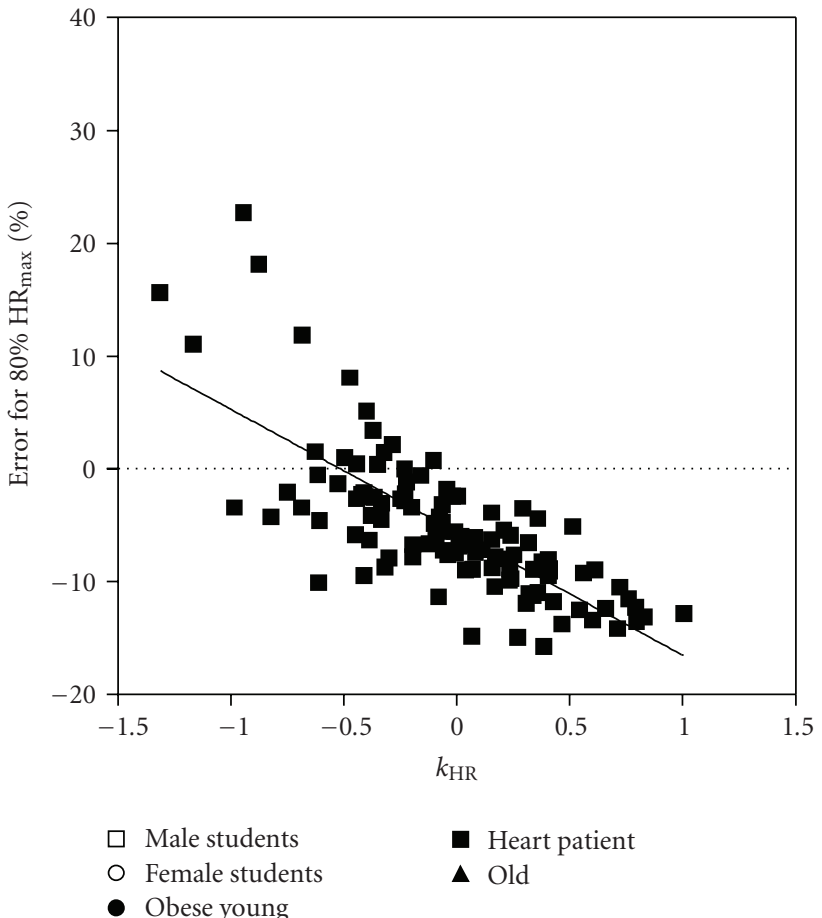

(c)

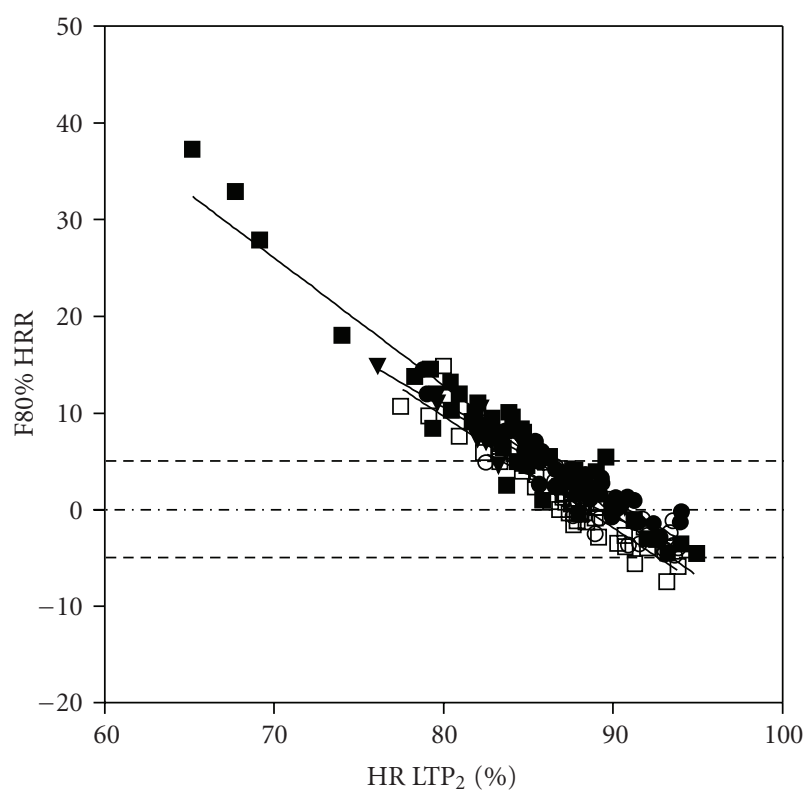

(b)

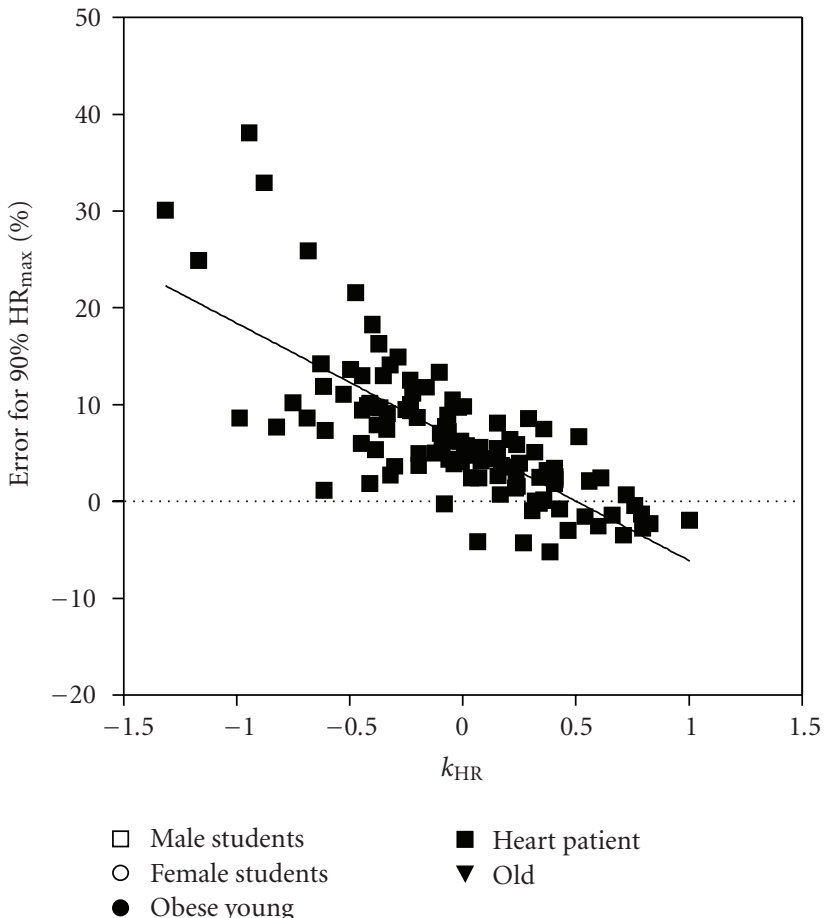

(d)

FIGURE 3: Error of estimate for percent heart rate reserve (HRR) compared to $\% \mathrm{HR}$ at the second lactate turn point (LTP 2 ) as well as the error of estimate for percent $\mathrm{HR}_{\max }$ related to the deflection of the heart rate performance curve (kHR) [29, 30] in healthy young male and female sports students, young obese subjects, older healthy subjects, and patients after myocardial infarction [31].

Numerous definitions and descriptions of these thresholds have been presented in the last decades [13].

To avoid any confusion, we therefore recommend to apply a nomenclature defining a first- $\left(\mathrm{TP}_{1}\right)$ and a secondturn point $\left(\mathrm{TP}_{2}\right)$ and denominate the turn points by the variable used to detect the turn point such as the first and the second turn points for lactate $\left(\mathrm{LTP}_{1}, \mathrm{LTP}_{2}\right)$, heart rate $\left(\mathrm{HRTP}_{1}, \mathrm{HRTP}_{2}\right)$ ventilation $\left(\mathrm{VETP}_{1}, \mathrm{VETP}_{2}\right)$ or the oxygen equivalent $\left(\mathrm{VE} / \mathrm{VO}_{2} \mathrm{TP}_{1}, \mathrm{VE} / \mathrm{VO}_{2} \mathrm{TP}_{2}\right)$ and the carbon dioxide equivalent $\left(\mathrm{VE} / \mathrm{VCO}_{2} \mathrm{TP}_{1}, \mathrm{VE} / \mathrm{VCO}_{2} \mathrm{TP}_{2}\right)$. 


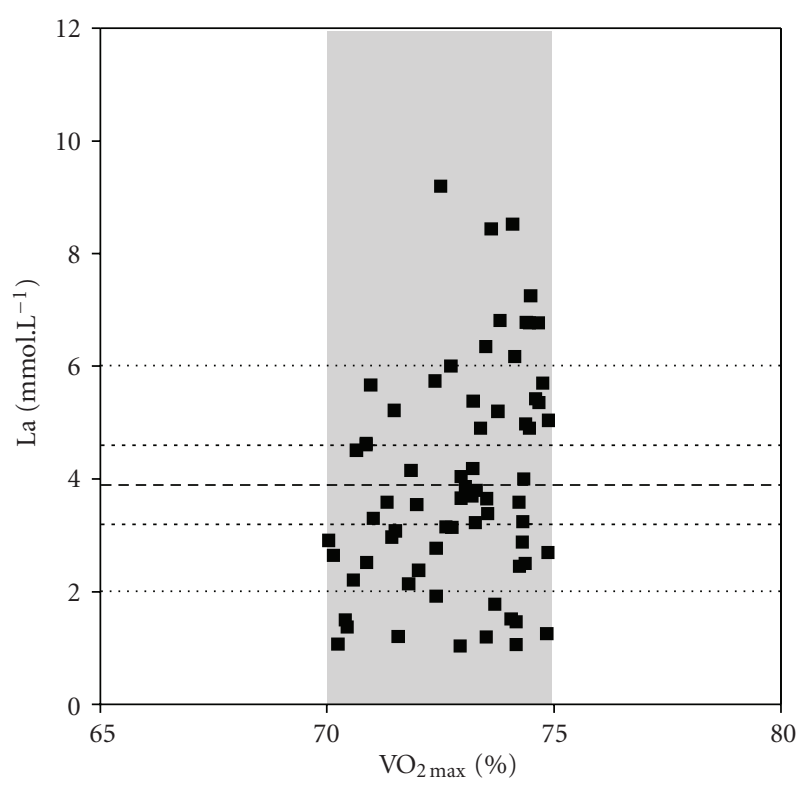

Figure 4: Mean blood lactate concentration (La) during constant load exercise in trained subjects applying controlled $70 \%-75 \%$ of $\mathrm{VO}_{2 \max }$ (unpublished results).

Figure 1 shows a schematic representation of the first and second turn points for these selected variables based on measures of 25 trained male subjects [31].

Using these objective individual turn points to prescribe exercise intensity allows for homogenous acute metabolic responses and uniform training stimuli across subjects yielding a reduction of health risk and enabling the comparison of results revealed by different training intervention studies.

The complex of problems associated with heterogeneous metabolic responses was pointed up by Hashimoto and Brooks [72] who argued that lactate is not only an oxidizable substrate and glucogenic precursor, but may also act as a pseudohormone called "lactormone" with a distinct signaling role. They nicely showed that lactate incubation upregulated hundreds of ROS-sensitive genes, suggesting the presence of a vast lactate-activated transcription network, a lactate transcriptome. This gives a good reason to postulate the use of exercise training regimes that induce similar metabolic responses across subjects. To ensure this demand, however, one has to respect the lactate shuttle theory [73] which implies a three-phase framework of the lactate performance curve with two distinct turn points [29-31] and three distinct phases of energy supply. Up to date there are no studies available applying such specifically tailored exercise protocols; however, some studies strongly support this assumption. Lamprecht et al. [74] showed that oxidative protein damage, as indicated by carbonyl protein oxidation, was significantly increased at intensities slightly above $\mathrm{LTP}_{2}\left(\mathrm{VT}_{2}\right)$ but was not at intensities below this turn point. Additionally, Jürimäe et al. [75] applied two constant workloads, one just below and one just above $\operatorname{HRTP}_{2}\left(\mathrm{VT}_{2}\right)$ in trained rowers. These authors showed that despite minimal heart rate differences of only $5 \mathrm{~b} \cdot \mathrm{min}^{-1}$ between two rowing exercise bouts just below or above $\mathrm{VT}_{2}$, growth hormone response was almost doubled in exercise above the $\mathrm{VT}_{2}$. Given these findings, the second turn point for La, HR, or VE $[29,30,65,71,76]$, consistent with the maximal lactate steady state $[67,76]$, seems to be a criterion for the upper level of exercise prescription in healthy subjects and patients.

In addition, the prescription of exercise intensity by means of the turn point concept is successfully applicable not only for constant load exercise, but also for interval-type exercise as recently shown by Tschakert et al. [77].

However, there are still some controversies about the "correct" concept of AT-determination to apply. Standards have been set for ventilatory threshold [62]; however, standard lactate-derived thresholds are still missing.

\section{Conclusions}

Exercise intensity plays a pivotal role to gain a sufficient training response without harmful side effects in healthy subjects and patients. Higher exercise intensities seem to be more beneficial; however, approaching the upper limits of exercise tolerance demands a more precise determination of these limits. Fixed percentages of $\mathrm{HR}_{\max }$ or $\mathrm{VO}_{2 \max }$ are not sufficient when approaching the upper limits and include some serious errors. For safety reasons, it may be concluded that the upper limit of target heart rate for exercise prescription should therefore not be assessed by means of a particular percentage of $\mathrm{HR}_{\max }, \mathrm{HRR}, \mathrm{VO}_{2 \max }$, or $\mathrm{VO}_{2} \mathrm{R}$, but by using intensities related to a certain threshold or turn point. The lactate turn point (LTP) concept gives a valid approach as it has a theoretical foundation and is consistent with other threshold determinations. As turn point concepts for lactate, heart rate, or ventilatory variables define these upper limits more precisely, this somewhat sophisticated approach is expected to be superior to the usual "art" of exercise prescription using fixed percentages and is therefore recommended by our working group especially for training studies. In addition, we ascertain that this definition of target training zones by means of turn points is necessary for trainings studies to obtain similar relative intensities and therefore comparable results for all study participants independent of their fitness level.

However, evidence regarding the most efficient training mode and intensity is still lacking. Further research is encouraged applying the turn point model describing distinct phases of energy supply to set exercise intensity standards for training intervention studies in patients.

\section{References}

[1] T. S. Church and S. N. Blair, "When will we treat physical activity as a legitimate medical therapy... even though it does not come in a pill?" British Journal of Sports Medicine, vol. 43, no. 2, pp. 80-81, 2009.

[2] U. M. Kujala, "Evidence on the effects of exercise therapy in the treatment of chronic disease," British Journal of Sports Medicine, vol. 43, no. 8, pp. 550-555, 2009. 
[3] D. E. R. Warburton, C. W. Nicol, and S. S. D. Bredin, "Health benefits of physical activity: the evidence," Canadian Medical Association Journal, vol. 174, no. 6, pp. 801-809, 2006.

[4] J. A. Jolliffe, K. Rees, R. S. Taylor, D. Thompson, N. Oldridge, and S. Ebrahim, "Exercise-based rehabilitation for coronary heart disease," Cochrane Database of Systematic Reviews, no. 1, Article ID CD001800, 2001.

[5] B. K. Pedersen and B. Saltin, "Evidence for prescribing exercise as therapy in chronic disease," Scandinavian Journal of Medicine and Science in Sports, vol. 16, no. 1, pp. 3-63, 2006.

[6] S. N. Blair, H. W. Kohl, C. E. Barlow, R. S. Paffenbarger, L. W. Gibbons, and C. A. Macera, "Changes in physical fitness and all-cause mortality: a prospective study of healthy and unhealthy men," Journal of the American Medical Association, vol. 273, no. 14, pp. 1093-1098, 1995.

[7] S. Sakamoto, N. Yokoyama, Y. Tamori, K. Akutsu, H. Hashimoto, and S. Takeshita, "Patients with peripheral artery disease who complete 12-week supervised exercise training program show reduced cardiovascular mortality and morbidity," Circulation Journal, vol. 73, no. 1, pp. 167-173, 2009.

[8] L. Sandvik, J. Erikssen, E. Thaulow, G. Erikssen, R. Mundal, and K. Rodahl, "Physical fitness as a predictor of mortality among healthy, middle-aged Norwegian men," New England Journal of Medicine, vol. 328, no. 8, pp. 533-537, 1993.

[9] N. Smart and T. H. Marwick, "Exercise training for patients with heart failure: a systematic review of factors that improve mortality and morbidity," American Journal of Medicine, vol. 116, no. 10, pp. 693-706, 2004.

[10] M. Wei, L. W. Gibbons, J. B. Kampert, M. Z. Nichaman, and S. N. Blair, "Low cardiorespiratory fitness and physical inactivity as predictors of mortality in men with type 2 diabetes," Annals of Internal Medicine, vol. 132, no. 8, pp. 605-611, 2000.

[11] U. Corr, F. Carré, P. Heuschmann et al., "Secondary prevention through cardiac rehabilitation: physical activity counselling and exercise training," European Heart Journal, vol. 31, no. 16, pp. 1967-1974b, 2010.

[12] ACSM's Guidelines for Exercise Testing and Prescription, Lippincott Williams \& Wilkins, Baltimore, Md, USA, 8th edition, 2010.

[13] R. K. Binder, M. Wonisch, U. Corra et al., "Methodological approach to the first and second lactate threshold in incremental cardiopulmonary exercise testing," European Journal of Cardiovascular Prevention and Rehabilitation, vol. 15, no. 6, pp. 726-734, 2008.

[14] F. Giada, A. Biffi, P. Agostoni et al., "Exercise prescription for the prevention and treatment of cardiovascular diseases: part I," Journal of Cardiovascular Medicine, vol. 9, no. 5, pp. 529544, 2008.

[15] F. Giada, A. Biff, P. Agostoni et al., "Exercise prescription for the prevention and treatment of cardiovascular diseases: part II," Journal of Cardiovascular Medicine, vol. 9, no. 6, pp. 641652, 2008

[16] A. Mezzani, P. Agostoni, A. Cohen-Solal et al., "Standards for the use of cardiopulmonary exercise testing for the functional evaluation of cardiac patients: a report from the exercise physiology section of the European association for cardiovascular prevention and rehabilitation," European Journal of Cardiovascular Prevention and Rehabilitation, vol. 16, no. 3, pp. 249-267, 2009.

[17] N. B. Nordsborg, C. Lundby, L. Leick, and H. Pilegaard, "Relative workload determines exercise-induced increases in PGC- $1 \alpha$ mRNA," Medicine and Science in Sports and Exercise, vol. 42, no. 8, pp. 1477-1484, 2010.
[18] ACSM's Resource Manual for Guidelines for Exercise Testing and Prescription, Lippincott Williams \& Wilkins, Baltimore, Md, USA, 6th edition, 2010.

[19] ACSM's Guidelines for Exercise Testing and Prescription, Lippincott Williams \& Wilkins, Baltimore, Md, USA, 7th edition, 2006.

[20] W. L. Haskell, I. M. Lee, R. R. Pate et al., "Physical activity and public health: updated recommendation for adults from the American College of Sports Medicine and the American Heart Association," Circulation, vol. 116, no. 9, pp. 1081-1093, 2007.

[21] M. E. Nelson, W. J. Rejeski, S. N. Blair et al., "Physical activity and public health in older adults: recommendation from the American College of Sports Medicine and the American Heart Association," Circulation, vol. 116, no. 9, pp. 1094-1105, 2007.

[22] G. F. Fletcher, G. J. Balady, E. A. Amsterdam et al., "Exercise standards for testing and training: a statement for healthcare professionals from the American Heart Association," Circulation, vol. 104, no. 14, pp. 1694-1740, 2001.

[23] L. S. Pescatello, B. A. Franklin, R. Fagard, W. B. Farquhar, G. A. Kelley, and C. A. Ray, "American College of Sports Medicine position stand. Exercise and hypertension," Medicine and science in sports and exercise, vol. 36, no. 3, pp. 533-553, 2004.

[24] N. F. Gordon, M. Gulanick, F. Costa, G. Fletcher, B. A. Franklin, and E. J. Roth, "Physical Activity and Exercise Recommendations for Stroke Survivors: an American Heart Association Scientific Statement from the Council on Clinical Cardiology, Subcommittee on Exercise, Cardiac Rehabilitation, and Prevention; the Council on Cardiovascular Nursing; the Council on Nutrition, Physical Activity, and Metabolism; and the Stroke Council," Circulation, vol. 109, no. 16, pp. 2031-2041, 2004.

[25] T. Meyer, H. H. W. Gabriel, and W. Kindermann, "Is determination of exercise intensities as percentages of $\mathrm{VO}_{2 \max }$ or $\mathrm{HR}_{\max }$ adequate?" Medicine and Science in Sports and Exercise, vol. 31, no. 9, pp. 1342-1345, 1999.

[26] F. Scharhag-Rosenberger, T. Meyer, N. Gäßler, O. Faude, and W. Kindermann, "Exercise at given percentages of $\mathrm{VO}_{2 \max }$ : heterogeneous metabolic responses between individuals," Journal of Science and Medicine in Sport, vol. 13, no. 1, pp. 74-79, 2010.

[27] V. O. Carvalho and A. Mezzani, "Aerobic exercise training intensity in patients with chronic heart failure: principles of assessment and prescription," European Journal of Cardiovascular Prevention \& Rehabilitation. In press.

[28] T. Meyer, M. Kindermann, and W. Kindermann, "Exercise programmes for patients with chronic heart failure," Sports Medicine, vol. 34, no. 14, pp. 939-954, 2004.

[29] P. Hofmann, S. P. Von Duvillard, F. J. Seibert et al., “\%HR target heart rate is dependent on heart rate performance curve deflection," Medicine and Science in Sports and Exercise, vol. 33, no. 10, pp. 1726-1731, 2001.

[30] P. Hofmann, R. Pokan, S. P. Von Duvillard, F. J. Seibert, R. Zweiker, and P. Schmid, "Heart rate performance curve during incremental cycle ergometer exercise in healthy young male subjects," Medicine and Science in Sports and Exercise, vol. 29, no. 6, pp. 762-768, 1997.

[31] P. Hofmann, G. Tschakert, R. Pokan, and S. P. VonDuvillard, "Three-phase time course of physiological variables during incremental cycling in young male and female subjects," Medicine and Science in Sports and Exercise, vol. 42, no. 5, p. 238, 2010, Abstract.

[32] J. A. Patterson, S. E. Selig, D. Toia, R. H. Geerling, V. Bamroongsuk, and D. L. Hare, "Comparing methods for 
prescribing exercise for individuals with chronic heart failure," Journal of Exercise Physiology Online, vol. 8, no. 4, pp. 9-19, 2005.

[33] J. Ilmarinen, K. Tuomi, L. Eskelinen, C. H. Nygard, P. Huuhtanen, and M. Klockars, "Background and objectives of the Finnish research project on aging workers in municipal occupations," Scandinavian Journal of Work, Environment and Health, vol. 17, no. 1, pp. 7-11, 1991.

[34] G. E. Duncan, S. D. Anton, S. J. Sydeman et al., "Prescribing exercise at varied levels of intensity and frequency: a randomized trial," Archives of Internal Medicine, vol. 165, no. 20, pp. 2362-2369, 2005.

[35] B. E. Jensen, B. J. Fletcher, J. C. Rupp, G. F. Fletcher, J. Y. Lee, and A. Oberman, "Training level comparison study: effect of high and low intensity exercise on ventilatory threshold in men with coronary artery disease," Journal of Cardiopulmonary Rehabilitation, vol. 16, no. 4, pp. 227-232, 1996.

[36] I. M. Lee and R. S. Paffenbarger, "Associations of light, moderate, and vigorous intensity physical activity with longevity: the Harvard Alumni Health Study," American Journal of Epidemiology, vol. 151, no. 3, pp. 293-299, 2000.

[37] D. P. Swain and B. A. Franklin, "Comparison of cardioprotective benefits of vigorous versus moderate intensity aerobic exercise," American Journal of Cardiology, vol. 97, no. 1, pp. 141-147, 2006.

[38] Ø. Rognmo, E. Hetland, J. Helgerud, J. Hoff, and S. A. Slørdahl, "High intensity aerobic interval exercise is superior to moderate intensity exercise for increasing aerobic capacity in patients with coronary artery disease," European Journal of Cardiovascular Prevention and Rehabilitation, vol. 11, no. 3, pp. 216-222, 2004.

[39] I. E. Schjerve, G. A. Tyldum, A. E. Tjønna et al., "Both aerobic endurance and strength training programmes improve cardiovascular health in obese adults," Clinical Science, vol. 115, no. 9, pp. 283-293, 2008.

[40] A. E. Tjønna, T. O. Stølen, A. Bye et al., "Aerobic interval training reduces cardiovascular risk factors more than a multitreatment approach in overweight adolescents," Clinical Science, vol. 116, no. 4, pp. 317-326, 2009.

[41] U. Wisløff, A. Støylen, J. P. Loennechen et al., "Superior cardiovascular effect of aerobic interval training versus moderate continuous training in heart failure patients: a randomized study," Circulation, vol. 115, no. 24, pp. 3086-3094, 2007.

[42] U. Wisløff, $\varnothing$. Ellingsen, and O. J. Kemi, "High-intensity interval training to maximize cardiac benefits of exercise training?" Exercise and sport sciences reviews, vol. 37, no. 3, pp. 139-146, 2009.

[43] P. Hofmann, M. Wonisch, R. Pokan, G. Schwaberger, G. Smekal, and S. P. Von Duvillard, " $\beta 1$-adrenoceptor mediated origin of the heart rate performance curve deflection," Medicine and Science in Sports and Exercise, vol. 37, no. 10, pp. 1704-1709, 2005.

[44] P. Hofmann, G. Tschakert, M. Stark et al., "Estimation error when using the \%HRR method compared to the lactate turn point," Medicine and Science in Sports and Exercise, vol. 41, supplement 5, pp. 221-222, 2009.

[45] K. Omiya, H. Itoh, N. Osada et al., "Impaired heart rate response during incremental exercise in patients with acute myocardial infarction and after coronary artery bypass grafting evaluation of coefficients with Karvonen's formula," Japanese Circulation Journal, vol. 64, no. 11, pp. 851-855, 2000.

[46] J.-Y. Tabet, P. Meurin, A. B. Driss et al., "Determination of exercise training heart rate in patients on $\beta$-blockers after myocardial infarction," European Journal of Cardiovascular Prevention and Rehabilitation, vol. 13, no. 4, pp. 538-543, 2006.

[47] M. Wonisch, P. Hofmann, F. M. Fruhwald et al., "Influence of beta-blocker use on percentage of target heart rate exercise prescription," European Journal of Cardiovascular Prevention and Rehabilitation, vol. 10, no. 4, pp. 296-301, 2003.

[48] R. Pokan, P. Hofmann, S. P. Von Duvillard et al., "The heart rate performance curve and left ventricular function during exercise in patients after myocardial infarction," Medicine and Science in Sports and Exercise, vol. 30, no. 10, pp. 1475-1480, 1998.

[49] I. Kjelkenes and E. Thorsen, "Anticipating maximal or submaximal exercise: no differences in cardiopulmonary responses," Clinical Physiology and Functional Imaging, vol. 30, no. 5, pp. 333-337, 2010.

[50] A. W. Midgley, L. R. McNaughton, R. Polman, and D. Marchant, "Criteria for determination of maximal oxygen uptake: a brief critique and recommendations for future research," Sports Medicine, vol. 37, no. 12, pp. 1019-1028, 2007.

[51] C. A. Brawner, S. J. Keteyian, and J. K. Ehrman, "The relationship of heart rate reserve to $\mathrm{VO}_{2}$ reserve in patients with heart disease," Medicine and Science in Sports and Exercise, vol. 34, no. 3, pp. 418-422, 2002.

[52] P. O. Åstrand, K. Rodahl, H. Dahl, and S. Strømme, Textbook of Work Physiology: Physiological Bases of Exercise, Human Kinetics, 4th edition, 2003.

[53] J. A. Zoladz and B. Korzeniewski, "Physiological background of the change point in $\mathrm{VO}_{2}$ and the slow component of oxygen uptake kinetics," Journal of Physiology and Pharmacology, vol. 52, no. 2, pp. 167-184, 2001.

[54] W. M. Kohrt, M. T. Malley, A. R. Coggan et al., "Effects of gender, age, and fitness level on response of $\mathrm{VO}_{2 \max }$ to training in 60-71 yr olds," Journal of Applied Physiology, vol. 71, no. 5, pp. 2004-2011, 1991.

[55] G. Lortie, J. A. Simoneau, P. Hamel, M. R. Boulay, F. Landry, and C. Bouchard, "Responses of maximal aerobic power and capacity to aerobic training," International Journal of Sports Medicine, vol. 5, no. 5, pp. 232-236, 1984.

[56] J. S. Skinner, A. Jaskólski, A. Jaskólska et al., "Age, sex, race, initial fitness, and response to training: the HERITAGE Family Study," Journal of Applied Physiology, vol. 90, no. 5, pp. 17701776, 2001.

[57] D. Hansen, P. Dendale, J. Berger, and R. Meeusen, "Rehabilitation in cardiac patients: what do we know about training modalities?" Sports Medicine, vol. 35, no. 12, pp. 1063-1084, 2005.

[58] C. Bouchard and T. Rankinen, "Individual differences in response to regular physical activity," Medicine and Science in Sports and Exercise, vol. 33, no. 6, pp. S446-S451, 2001.

[59] J. S. Skinner, S. E. Gaskill, T. Rankinen et al., "Heart rate versus $\% \mathrm{VO}_{2 \max }$ : age, sex, race, initial fitness, and training responseHERITAGE," Medicine and Science in Sports and Exercise, vol. 35, no. 11, pp. 1908-1913, 2003.

[60] J. M. Jakicic, J. E. Donnelly, N. P. Pronk, A. F. Jawad, and D. J. Jacobsen, "Prescription of exercise intensity for the obese patient: the relationship between heart rate, $\mathrm{VO}_{2}$ and perceived exertion," International Journal of Obesity, vol. 19, no. 6, pp. 382-387, 1995.

[61] K. Okita, K. Yonezawa, H. Nishijima et al., "Skeletal muscle metabolism limits exercise capacity in patients with chronic heart failure," Circulation, vol. 98, no. 18, pp. 1886-1891, 1998. 
[62] T. Meyer, A. Lucía, C. P. Earnest, and W. Kindermann, "A conceptual framework for performance diagnosis and training prescription from submaximal gas exchange parameterstheory and application," International Journal of Sports Medicine, vol. 26, no. 1, pp. S38-S48, 2005.

[63] D. Salvadego, S. Lazzer, C. Busti et al., "Gas exchange kinetics in obese adolescents. Inferences on exercise tolerance and prescription," American Journal of Physiology, vol. 299, no. 5, pp. R1298-R1305, 2010.

[64] H. A. Davis, J. Bassett, P. Hughes, and G. C. Gass, "Anaerobic threshold and lactate turnpoint," European Journal of Applied Physiology and Occupational Physiology, vol. 50, no. 3, pp. 383392, 1983.

[65] P. Hofmann, H. Leitner, and G. Gaisl, "Heart rate threshold, lactate turn point andanaerobic threshold determination by electromyography," Hungarian Review of Sports Medicine, vol. 33, no. 1, pp. 13-20, 1992.

[66] P. Hofmann, R. Pokan, K. Preidler et al., "Relationship between heart rate threshold, lactate turn point and myocardial function," International Journal of Sports Medicine, vol. 15, no. 5, pp. 232-237, 1994.

[67] P. Hofmann, V. Bunc, H. Leitner, R. Pokan, and G. Gaisl, "Heart rate threshold related to lactate turn point and steadystate exercise on a cycle ergometer," European Journal of Applied Physiology and Occupational Physiology, vol. 69, no. 2, pp. 132-139, 1994.

[68] S. Aunola and H. Rusko, "Does anaerobic threshold correlate with maximal lactate steady-state?" Journal of Sports Sciences, vol. 10, no. 4, pp. 309-323, 1992.

[69] J. S. Skinner and T. H. McLellan, "The transition from aerobic to anaerobic metabolism," Research Quarterly for Exercise and Sport, vol. 51, no. 1, pp. 234-248, 1980.

[70] K. Wasserman and M. B. McIlroy, "Detecting the threshold of anaerobic metabolism in cardiac patients during exercise," The American Journal of Cardiology, vol. 14, no. 6, pp. 844-852, 1964.

[71] P. Hofmann, T. Jürimäe, J. Jürimäe et al., "HRTP, prolonged ergometer exercise, and single sculling," International Journal of Sports Medicine, vol. 28, no. 11, pp. 964-969, 2007.

[72] T. Hashimoto and G. A. Brooks, "Mitochondrial lactate oxidation complex and an adaptive role for lactate production," Medicine and Science in Sports and Exercise, vol. 40, no. 3, pp. 486-494, 2008.

[73] G. A. Brooks, "Cell-cell and intracellular lactate shuttles," Journal of Physiology, vol. 587, no. 23, pp. 5591-5600, 2009.

[74] M. Lamprecht, J. F. Greilberger, G. Schwaberger, P. Hofmann, and K. Oettl, "Single bouts of exercise affect albumin redox state and carbonyl groups on plasma protein of trained men in a workload-dependent manner," Journal of Applied Physiology, vol. 104, no. 6, pp. 1611-1617, 2008.

[75] J. Jürimäe, P. Hofmann, T. Jürimäe et al., "Plasma ghrelin responses to acute sculling exercises in elite male rowers," European Journal of Applied Physiology, vol. 99, no. 5, pp. 467474, 2007.

[76] M. Wonisch, P. Hofmann, F. M. Fruhwald et al., "Effect of $\beta$ selective adrenergic blockade on maximal blood lactate steady state in healthy men," European Journal of Applied Physiology, vol. 87, no. 1, pp. 66-71, 2002.

[77] G. Tschakert,, W. Groeschl, G. Schwaberger, S. P. Von Duvillard, and P. Hofmann, "Prescription for aerobic high-intensity interval training by means of incremental exercisetests markers," Medicine and Science in Sports and Exercise, vol. 41, supplement 5, p. 430, 2009. 


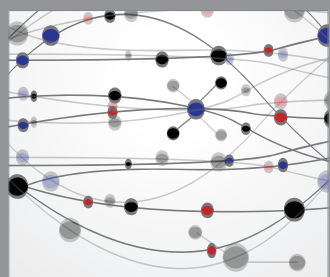

The Scientific World Journal
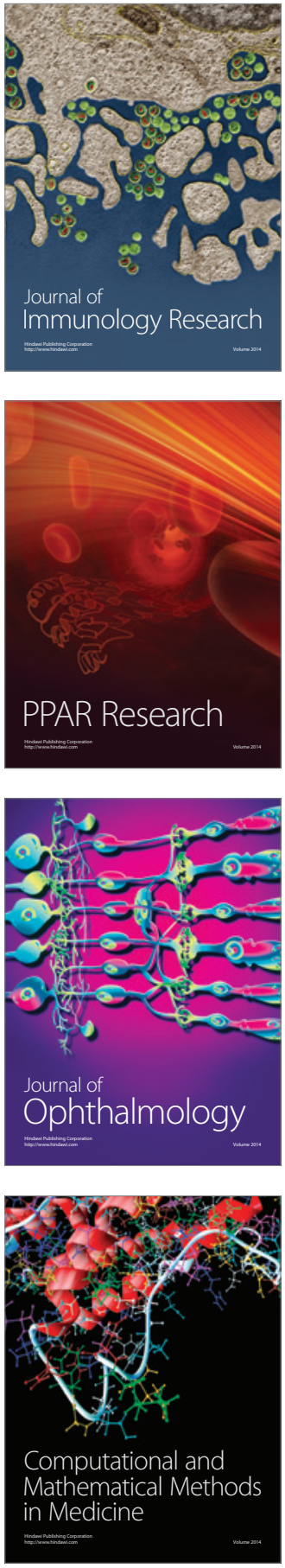

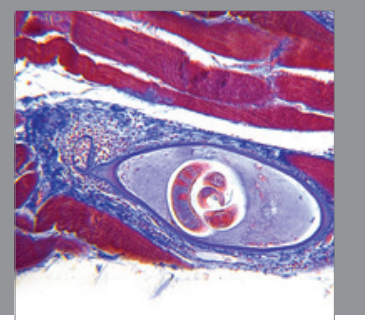

Gastroenterology

Research and Practice
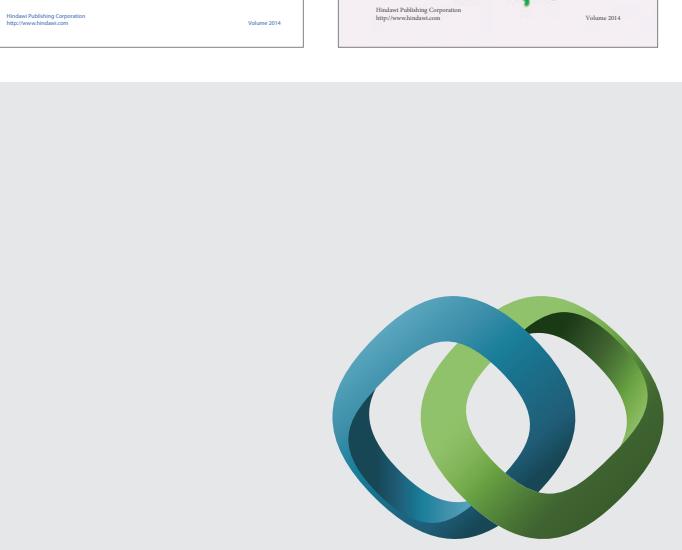

\section{Hindawi}

Submit your manuscripts at

http://www.hindawi.com
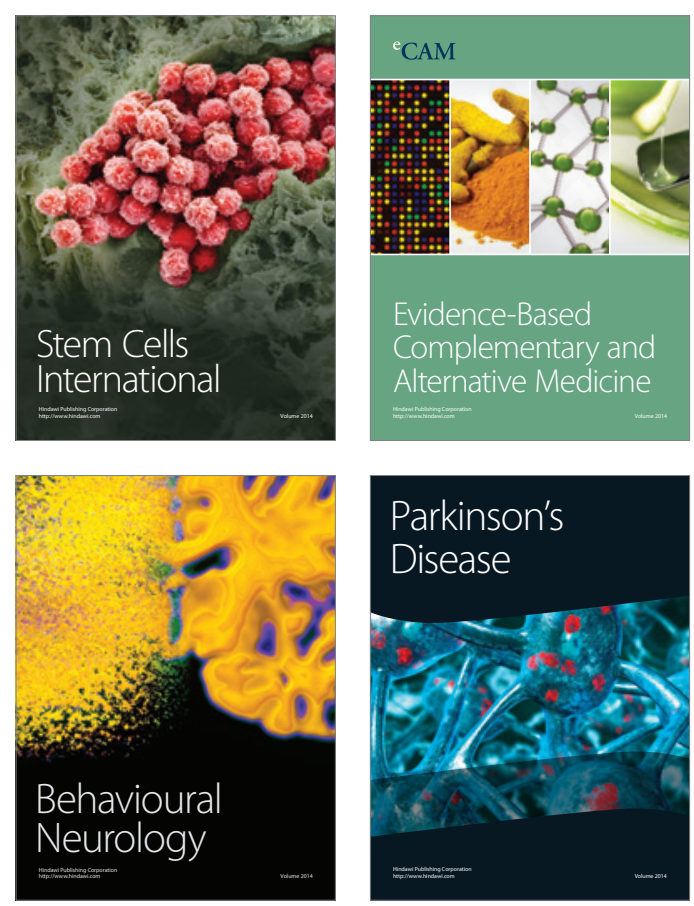

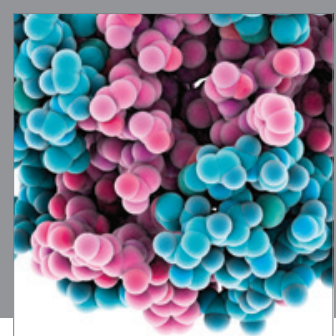

Journal of
Diabetes Research

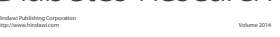

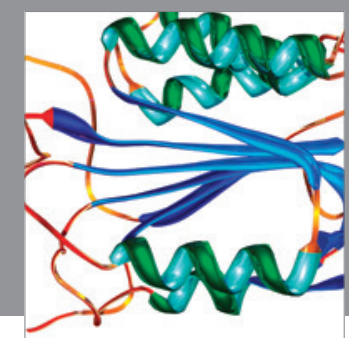

Disease Markers
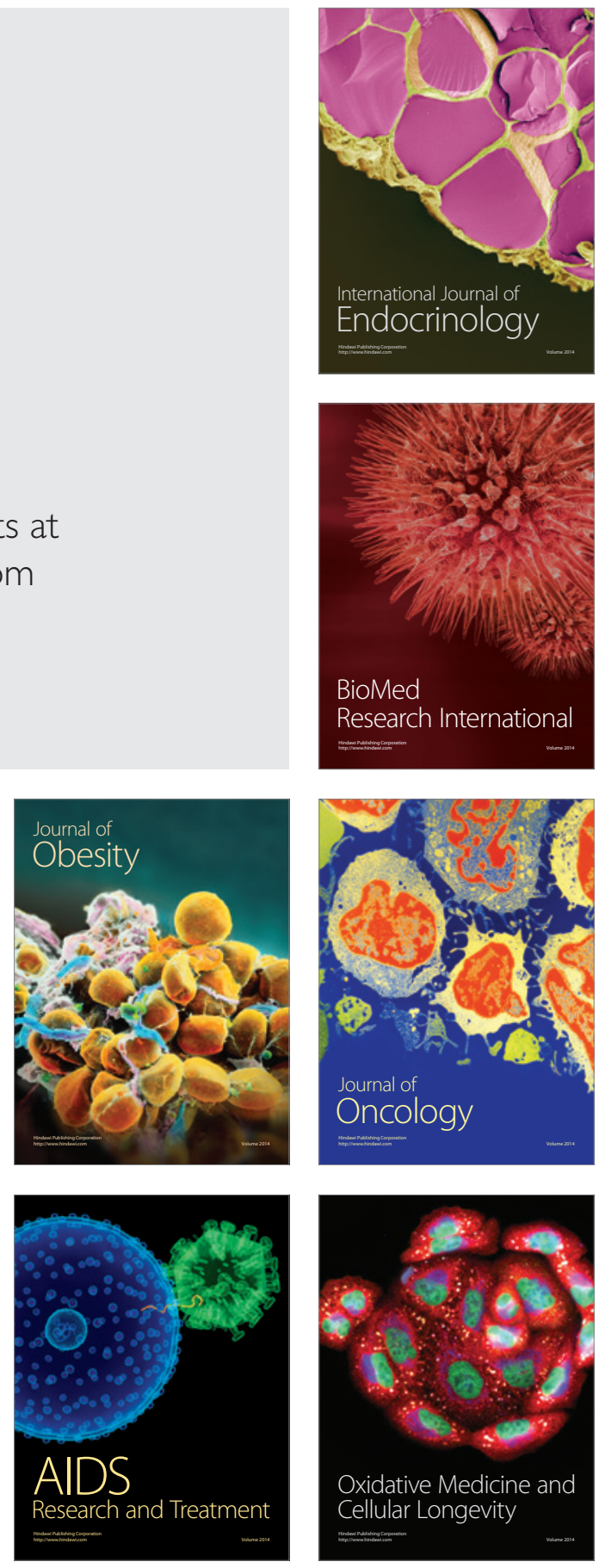